\title{
The Holistic Effects of Climate Change on the Culture, Well-Being, and Health of the Saami, the Only Indigenous People in the European Union
}

\author{
Jouni J. K. Jaakkola ${ }^{1}$ S Suvi Juntunen ${ }^{1} \cdot$ Klemetti Näkkäläjärvi $^{2}$
}

Published online: 22 October 2018

(C) The Author(s) 2018

\begin{abstract}
Purpose of Review (1) To develop a framework for understanding the holistic effects of climate change on the Saami people; (2) to summarize the scientific evidence about the primary, secondary, and tertiary effects of climate change on Saami culture and Sápmi region; and (3) to identify gaps in the knowledge of the effects of climate change on health and well-being of the Saami. Recent Findings The Saami health is on average similar, or slightly better compared to the health of other populations in the same area. Warming climate has already influenced Saami reindeer culture. Mental health and suicide risk partly linked to changing physical and social environments are major concerns.

Summary The lifestyle, diet, and morbidity of the Saami are changing to resemble the majority populations posing threats for the health of the Saami and making them more vulnerable to the adverse effects of climate change. Climate change is a threat for the cultural way of life of Saami. Possibilities for Saami to adapt to climate change are limited.
\end{abstract}

Keywords Climate change $\cdot$ Saami people $\cdot$ Reindeer herding $\cdot$ Systematic review $\cdot$ Public health $\cdot$ Adaptation

\section{Introduction}

From the global perspective, the indigenous people in the Artic constitute potentially the most vulnerable population to the effects of climate change for two reasons. They live in close interaction with the natural environment and the climate change and its effects to environmental conditions including temperature are most impactful in the Arctic [1]. Therefor, indigenous people could be regarded as the first population indicators of the effects of harmful environmental condition and change. From the perspective of the indigenous people, climate change has been regarded as one of the most extensive threats to health and well-being [2]. In addition to climate change, environmental change related to natural and human-

Topical Collection on Global Environmental Health and Sustainability

Jouni J. K. Jaakkola

jouni.jaakkola@oulu.fi

1 Center for Environmental and Respiratory Health Research, University of Oulu, P. O. Box 5000, FI-90014 Oulu, Finland

2 Department of Social Sciences, University of Lapland, Rovaniemi, Finland based reasons, continued regional economic development, and prolific utilization of natural resources constitute similar threats to health, well-being as well as to the entire culture. ${ }^{1}$

The average temperature in the Arctic has already risen from the preindustrial period [3]. The effects of climate change in the Polar Regions are expected to be globally the most pronounced [1]. Conditions in the Sápmi region have changed during postindustrial period, including the timing of snowmelt and the length of thermal seasons [3, 4].

Around 40 indigenous peoples inhabit the Arctic Region forming $10 \%$ of the total population in this region. The present article focusses on the Saami (in North Saami: Sámi), the indigenous people living in the northern parts of Norway, Sweden, Finland, and Kola Peninsula in Russia. Many of the phenomena related to the Saami are likely to be generalizable to the other indigenous populations. On the basis of a priori knowledge, we hypothesized that the effects of climate change are likely to be holistic, influencing not just health and well-being, but the entire culture. Our overall objective was to elaborate the holistic effects of climate change on the Saami.

\footnotetext{
${ }^{1}$ In this study we use the term lifestyle according to Saami understanding. It refers to, inter alia, Saami way of life, values, social structure, traditions, and customs. It includes the tradition of Saami livelihoods, identity, and lingual heritage and habitation pattern.
} 
The specific objectives of the study were (1) to develop a framework for understanding the holistic effects of climate change on the Saami people and Arctic indigenous people in general; (2) to summarize the scientific evidence about the primary, secondary, and tertiary effects of climate change to Saami culture and to Sápmi region; and (3) to identify gaps in the knowledge of the effects of climate change on health and well-being of the Saami.

\section{Methods}

\section{Saami People}

The traditional settlement area is called Sápmi (land of the Saami) in the North Saami language. The population of Saami people is estimated at 50,000-70,000 in Norway [5], over 10,000 in Finland [6], 20,000-35,000 in Sweden [7••], and 2000 in Russia [8]. Approximately half of the Saami speak Saami as their native language. All Saami languages are classified as endangered or highly endangered [9]. Traditional Saami livelihoods include reindeer herding, fishing, hunting, handicrafts (duodji), and gathering. Reindeer herding is the most viable livelihood. Many of the Saami reindeer-herding families are also involved in Saami handicrafts, fishing, and gathering. In Sweden and Norway, practically only the Saami can practice reindeer herding. At present many Saami are occupied outside traditional livelihoods and many, especially youth, have migrated to urban regions outside Sápmi [10].

\section{Framework and Theory}

The main proposition is that the global change driven by the anthropogenic climate change is influencing entire cultures of the indigenous populations in the Artic (Fig. 1). We conceptualized the complex causal web schematically in Figs. 2 and 3. Figure 2a is an extension of the framework of the Center for Environmental and Respiratory Health Research multidisciplinary research program established in 2009 [11]. In the present form, "public health" appearing in the center was replaced with "culture, well-being, and health". The arrows from Global change illustrate how the effects of global change are hypothesized to be mediated through climate, air, water, and soil pollution, housing, and life style. Figure 2a explains the multi-dimensional, direct and indirect effects of climate change to culture, well-being, and health.

We apply the proposition of Butler and Harley to divide the health effects of climate change into the primary, secondary, and tertiary effects. The primary effects arise from the direct changes and impacts of the physical system. The secondary effects arise due to alternations in the ecology of vectors, parasites, and host animals, and effects mediated by the allergens and air pollutants are included in this category. The tertiary effects refer to wider scale of effects caused by intersection of climate, politics, and ecology, both human and nonhuman $[12 \bullet \cdot]$. Our framework in the Saami context is expanded to cover cultural and social effects of climate change. Cultural and social effects are likely to influence health and well-being.

Figure $2 \mathrm{a}, \mathrm{b}$ describes the different methodological approaches to understand the factors effecting Saami health and cultural well-being in a changing climate and the main forces driving the global change.

Figure 2a describes the central research disciplines and research methods that applied to study the holistic effects of climate change on Saami culture. Figure $2 b$ describes the ethno-ecological niche $[13,14]$ of Saami people and the changing framework of their culture. The niche includes the individual and the siida that is kinship-based Saami communal structure that manages reindeer work in its own area. Each siida has its own pasture areas, but the siida system is very flexible [15]. The cultural ecological framework of the niche consists of the eallu (the reindeer) and biodiversity. Saami people and culture are not isolated but part of larger Saami community and national society with its legislation, practices, education system, and jurisprudence. Climate change has been identified as a new framework for Saami culture and livelihoods due to its far-reaching and holistic influences [16••, 17•].

\section{Literature Search and Complementary Evidence}

We conducted a systematic literature review on peerreviewed publications covering any articles on (1) Saami people; (2) Saami reindeer herding; and (3) climate change and its effects on the Saami and the Sápmi region. We focused only on studies providing empirical research data, either qualitative or quantitative. The inclusion criteria were that the article provided information on (1) Saami culture, health, well-being and/or livelihoods; and (2) the effects of climate change on the Sápmi and Saami livelihoods. Keywords were selected based on tests of different keywords in academic search engines. Articles published in 1990-2017 were included.

In addition to the systematic literature search, we included evidence from an ethnographic fieldwork conducted by Dr. Näkkäläjärvi, which included interviews of 30 reindeer herders from four Saami communities in Finland 2015-2017, during the conduct of this systematic review. These interviews provided important insight into the holistic effects of climate change perceived by reindeer herders and it influenced the development of the theoretical framework. 
Fig. 1 Flowchart of the systematic literature search

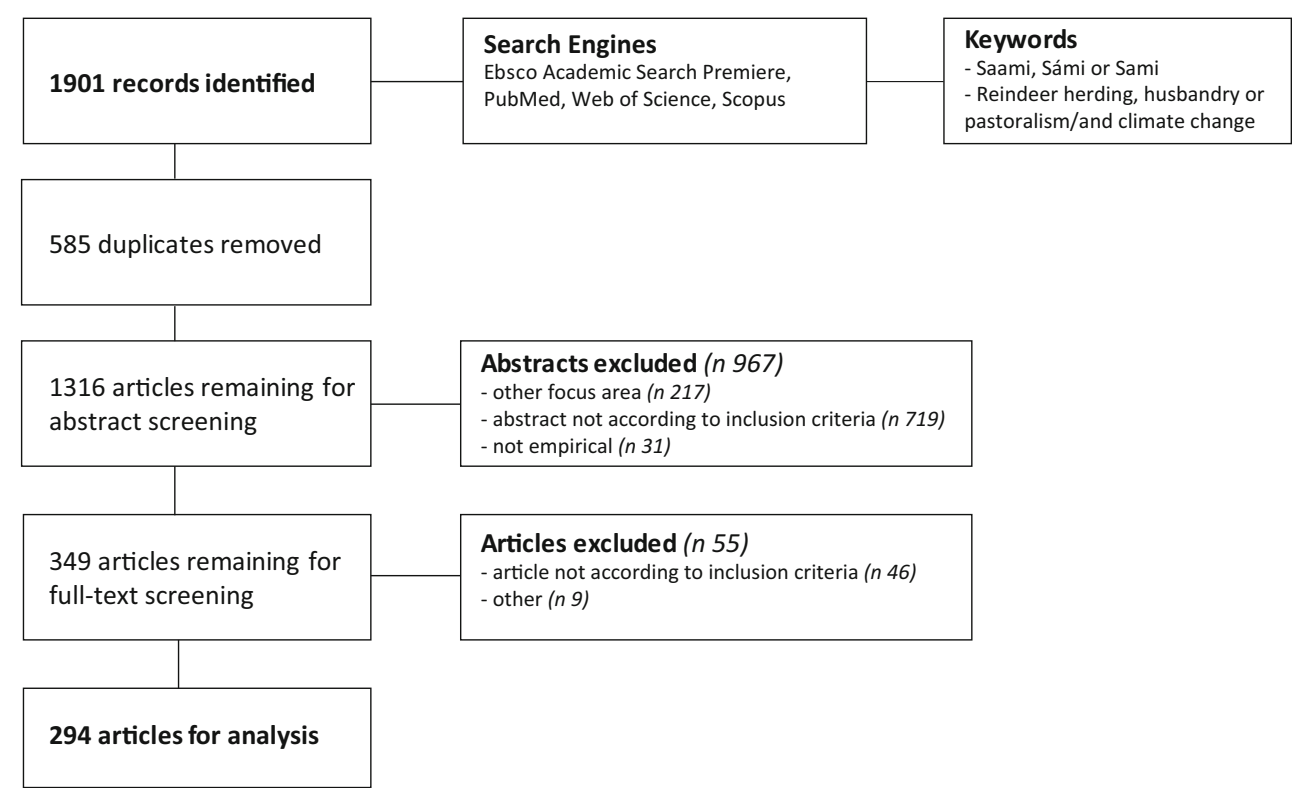

\section{Results}

\section{Literature Search and Characteristics of Studies}

Figure 1 present a flowchart of the search strategy. The primary search identified 294 studies, 126 conducted in Norway (43\%), 83 in Sweden (28\%), 51 in Finland (17\%), only 12 covered Russia (4\%), and 22 were multinational (8\%). Table 1 provides an overview on main study topics. Most of the studies characterize the environment, culture, livelihoods, and health without any consideration of the role of climate change.

\section{Environment, Livelihoods, and Culture}

Traditional Saami settlement area includes both sub-arctic and arctic areas with boreal forest, coastal areas, and large mountain regions with alpine vegetation. Snow covers the Sápmi area 8 months a year, and plays a central role in the climatic, ecological, and hydrological processes, and in the way of life and reindeer herding [18]. Saami language has a precise classification system for snow and knowledge of snow is an important part of reindeer herder's knowledge [19]. Reindeer is important for Saami culturally and reindeer herding is means to maintain traditions, language, and cultural identity in changing world. Reindeer herding, as other traditional Saami livelihoods constitute important part of Saami well-being (see Fig. 4). Currently, reindeer herding is one of the driving forces together with other herbivore on shaping the vegetation in Sápmi region [20]; however, in boreal area forestry and competing land uses, such as mining, infrastructure development, and tourism affect both vegetation and reindeer herding [21, 22]. Although reindeer forage over 300 different plants in addition to fungi, ground lichen is the main forage for reindeer in winter. Lichen heaths are in heavily grazed areas and in areas where forestry and reindeer grazing coexist degraded, but there are regional differences in grazing pressure [23-25]. Human activity influences the range a
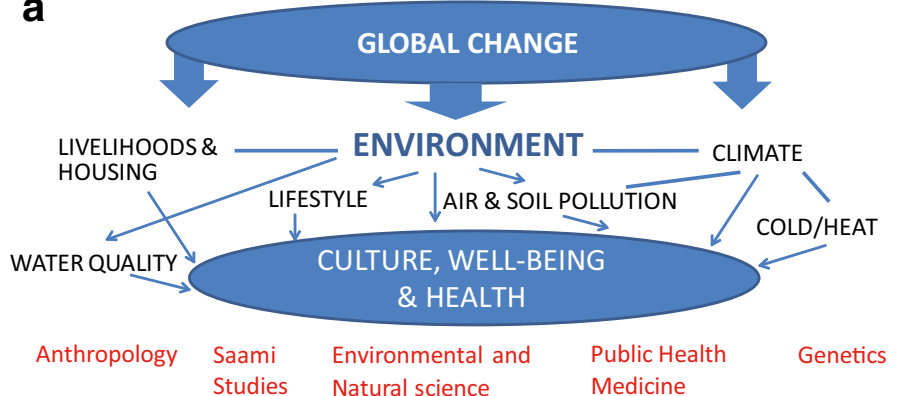

EPIDEMIOLOGICAL QUALITATIVE META-ANALYSIS BURDEN OF DISEASE $\begin{array}{lll}\text { METHODS METHODS ASSESSMENT } & \end{array}$ b

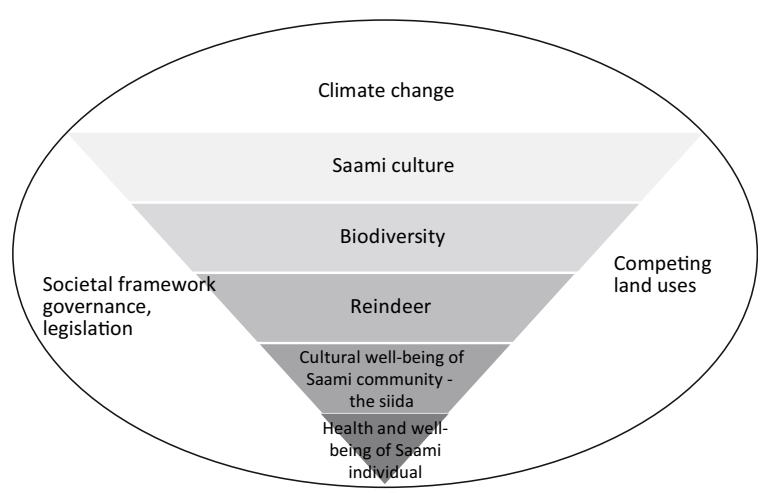

Fig. 2 a Conceptual framework of the study. b Main factors influencing the health and well-being of Saami individual in reindeer-herding community 


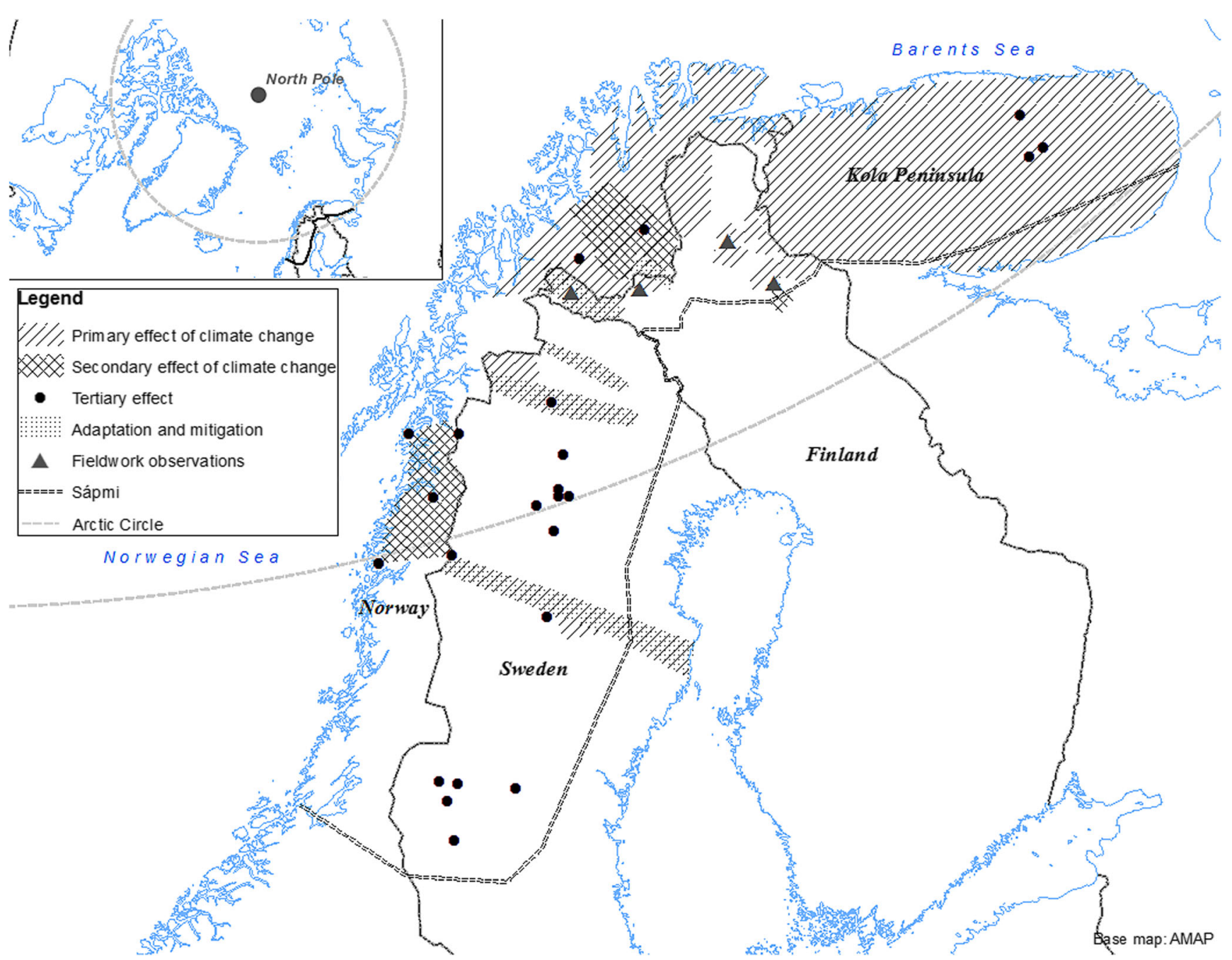

Fig. 3 Local observations on the effects of climate change in Sápmi region based on the present systematic literature research and complementary fieldwork by Dr. Näkkäläjärvi

selection of reindeer, and increase grazing pressure inside the reindeer-herding area [26, 27], but there is also evidence that reindeers can locally habituate towards human activities [28]. Predation influences significantly the mortality among reindeers, but the effects on the total reindeer demography and livelihood are debated. Losses are compensated for the reindeer herders $[29,30,31 \bullet]$.

Saami reindeer herding is distinctively inherited profession and kin-ties are important for reindeer management. [32]. Reindeer herding is connected to Saami well-being so that the quality of life decrease if the livelihood is lost [33]. Women constitute a minority of full-time reindeer herders, being actively involved in reindeer-herding culture [34••]. Evidence from Sweden suggests that there are gender differences in the status of reindeer herder, and different expectations for women [35].

Saami reindeer herding has adopted new technology and methods such as supplementary feeding. It is argued, that these changes have increased the adaptive capacity of reindeer herding, but increased the dependence on subsidies $[26,36]$.
However, there are regional variations in different reindeerherding models and in the use of new methods. Modernization has created social and economic pressures for the reindeerherding communities. Small proportion of Saami reindeer herders is involved in tourism services, which provide better income and concurrently offers means to maintain traditional livelihood [36-38]. Governance and market economy have forced Saami to change their reindeer-herding model in Kola Peninsula. Industrialization has influenced Saami to abandon their culture $[39,40]$.

Assimilation measures have caused significant loss of Saami language; but language revitalization measures have improved the situation $[8,41]$. The smallest Saami languages alive have only few speakers and it is likely that language loss will continue in the near future. Traditional Saami home regions are located in rural areas with sparse population. Outmigration to urban areas is an increasing trend, but the potential effects of outmigration to demography, Saami society social, and culture have not yet been explored. Migrants are 
Table 1 Published articles on Saami health and well-being by the main topic and country, 1990-2017

\begin{tabular}{|c|c|c|c|c|c|c|c|c|c|}
\hline \multirow[t]{2}{*}{ Topic } & \multicolumn{2}{|c|}{ Norway } & \multicolumn{2}{|c|}{ Sweden } & \multicolumn{2}{|c|}{ Finland } & \multicolumn{2}{|c|}{ Russia } & \multirow[t]{2}{*}{ Total } \\
\hline & $n$ & Publication year & $n$ & Publication year & $n$ & Publication year & $n$ & Publication year & \\
\hline General health & 20 & $1999,2002-2016$ & 3 & 2010-2013 & 2 & 1997, 2002 & 1 & 1999 & 26 \\
\hline Cause-specific mortality & 3 & 2006-2009 & 5 & 2004-2012 & 5 & 1995-1999, 2008 & 0 & & 13 \\
\hline Occupational health & 0 & - & 4 & 2004-2008, 2017 & 5 & 1991-1994, 2006 & 0 & & 9 \\
\hline Asthma and allergies & 2 & 1999 and 2002 & & & 1 & 1991 & 0 & & 3 \\
\hline Cardiovascular diseases & 4 & $1998,2013-2014$ & 2 & 2004-2008 & 3 & 1995-1997, 2001 & 0 & & 9 \\
\hline Diabetes & 3 & $1998,2016-2017$ & & & 0 & & 0 & & 3 \\
\hline Cancer & 1 & 2005 & 3 & 2002, 2008-2014 & 3 & 2002, 2010-2012 & 0 & & 7 \\
\hline Genetic diseases and genetics & 9 & $\begin{array}{l}\text { 1992-1994, } \\
2002-2008\end{array}$ & 2 & 2004,2008 & 3 & 1998-2001 & 4 & 1997-1999, 2008-2017 & 18 \\
\hline Mental health & 27 & $1998,2000-2017$ & 7 & 2010-2017 & 1 & 1994 & 0 & & 35 \\
\hline Dental health & 0 & & 4 & 2006-2014 & 0 & & 0 & & 4 \\
\hline Environmental exposures & 2 & 1999, 2014 & & & 3 & 1999, 2003-2009 & 1 & 1999 & 6 \\
\hline Nuclear fallout and radiation & 4 & $1996,2000-2015$ & 4 & 1990-1999, 2014 & 2 & 2005-2010 & 0 & & 10 \\
\hline Diet and lifestyle & 9 & 1999-03, 2007-2017 & 7 & $1999,2004-2013$ & 2 & 1995 & 1 & 2008 & 18 \\
\hline Substance use & 7 & 1990, 2002-2011 & 2 & 2011,2015 & 0 & & & & 9 \\
\hline Cultural well-being & 16 & 1996-1998, 2003-2017 & 6 & $2006-2015$ & 3 & $1995,2010-2016$ & 0 & & 25 \\
\hline Discrimination & 7 & 2008-2015 & 2 & 2011-2012 & 0 & & 0 & & 7 \\
\hline Violence & 3 & 2015-2017 & & & 0 & & 0 & & 3 \\
\hline Health services & 15 & 2005-2013 & 1 & 2013 & 1 & 2012 & 0 & & 17 \\
\hline TOTAL & 135 & & 52 & & 34 & & 7 & & \\
\hline
\end{tabular}

characterized as young and mostly female [42]. Outmigration influences the communal viability, coherence, and vitality of the traditional Saami regions, and poses challenges to the cultural well-being of the migrants.

Saami and their livelihoods are vulnerable and exposed to socioeconomic changes and top-down governance. Adaptive capacity of Saami reindeer herding is limited geographically and in terms of governance $[31 \bullet, 43]$. Small population size and social and assimilative legacy pose serious challenges for the possibilities of Saami to maintain their culture and way of life in changing climate.

\section{Saami Lifestyle and Well-Being}

It has been suggested that genetics together with Saami traditional lifestyle that includes significant physical activity and a healthy diet including reindeer meat, fish, and berries have positive effects on the Saami health reducing the risk of chronic diseases typically linked to western lifestyle [44-47]. Unfortunately, there is evidence that the lifestyle is changing: Saami experience less physical activity and traditional diet is, especially outside Saami core areas, being partly or completely replaced with western diet [48-51]. Saami women are in
Fig. 4 Simplified presentation on causal effects of climate change to the health and cultural well-being of Saami in Reindeer livelihood context

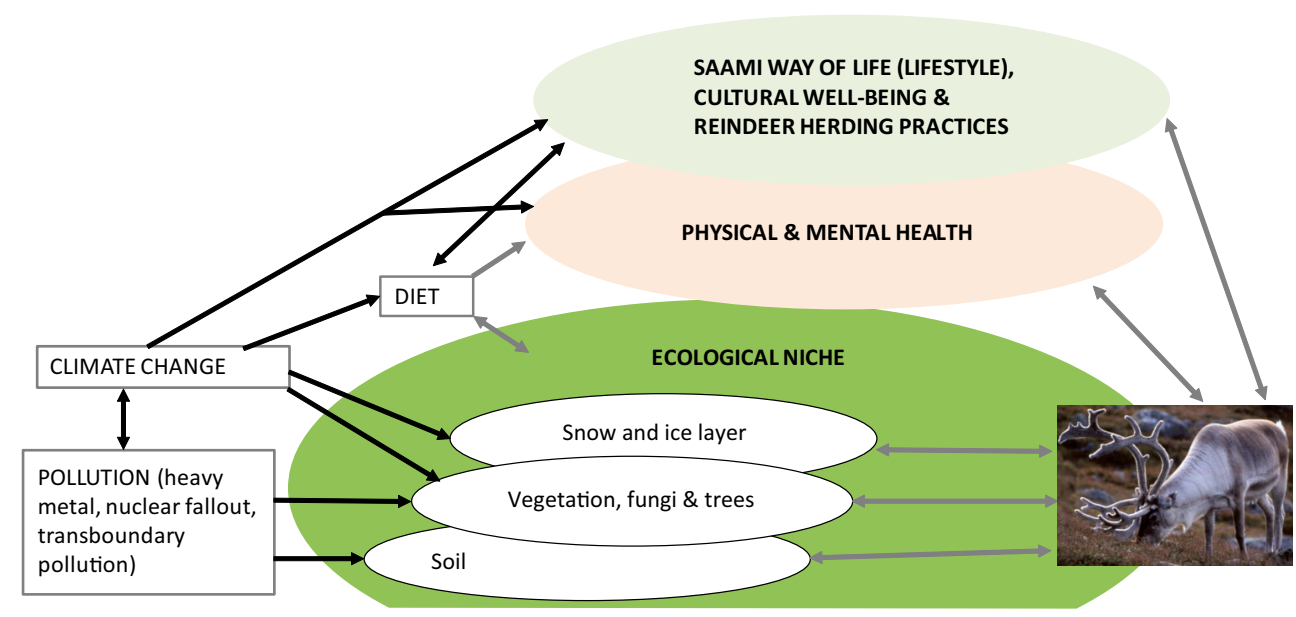


general more obese than women population in the same area. Saami men are less obese than the other population in the same area [52]. Obesity is a risk factor for pre-diabetes and diabetes mellitus. The findings indicate that if the cultural and socioeconomic changes continue among Saami population effecting the traditional lifestyle and diet, it is likely that diabetes mellitus will become a public health concern among Saami population. Change or loss in traditional diet also indicates change in cultural values, livelihoods, and lifestyle.

Recent studies found no differences in the substance use between the Saami and the majority population in Norway $[53,54]$ and Sweden $[55,56]$. However, $50 \%$ of non-natural deaths among Saami reindeer herders in Sweden occurred under the influence of alcohol [57•].

In Northern Norway, the Saami were subjected to violence more than the general population; 22\% Saami women experienced sexual violence [58]. Several findings from Sweden and Norway indicate that a major part of Saami population has experienced ethnic discrimination and it has negative implications to mental well-being and quality of life [59, 60]. Several important cultural and social factors, such as living in Saami core areas, involvement in reindeer herding, Saami as a native language, strong family ties, and communality, seem to protect Saami from mental health problems and provide resilience towards ethnic discrimination [60-62].

\section{Health and Well-Being}

Several population-based epidemiologic studies have estimated cause-specific mortality and the occurrence of chronic diseases between the Saami and the majority population. Main results are summarized in Table 2. The Saami health is on average similar, or slightly better compared to the health of other populations in the same area in Finland, Norway, and Sweden $[7 \bullet \bullet$.

Unfortunately, the findings also indicate that cultural and language loss among Saami population due to assimilation policies produces mental and social problems among Saami and the burden is passed on to future generations [65]. The studies have also indicated that living outside Saami core area, loose connection to Saami livelihoods and culture and loss of Saami language can increase mental health problems and decrease resilience towards ethnic discrimination [61, 62]. Saami adolescents living outside Saami core areas use more practitioner's services than Saami in the core area or peer living in the same area [66]. This indicates that Saami are willing to seek help for their problems and living outside Saami core areas brings health challenges for Saami. A new emerging threat for Saami mental health is hopelessness and fear for the future identified in a qualitative study among Saami youth. Loss of Saami livelihood, weakened possibilities to maintain Saami culture and poor legal status are estimated to pose a serious mental health risk and impact on suicidal behavior [63・•].

Living in Saami core areas, involvement in reindeer herding, Saami as a native language, strong family ties and communality, and possibility to maintain Saami culture and livelihoods increase Saami well-being [60-62, 64, 66].

\section{Primary Effects of Climate Change}

Studies on the primary effects of climate change were focused on ongoing and past changes in the vegetation and climate and the climate scenarios (see Fig. 3) in Sápmi. Local observations by reindeer herders and studies confirm that climate change has already altered conditions in Sápmi region. The most prominent are changes in snow cover and vegetation. The ethnographic interviews by Dr. Näkkäläjärvi provided evidence that observations on these changes are common and consistent among reindeer herders. Shrub expansion is occurring rapidly in tundra and mountain range, and the tree line is moving north- and upwards $[67,68]$.

It is estimated that the days with snow cover are significantly shortened, but regional differences can be important. Winter thaws, rain-on-snow and refreezing events that are projected to increase creating ice crust $[18,69]$, and have a negative effect on reindeer pasture conditions, since reindeer cannot dig nutrition underneath ice cover. Climate change increases the risk of wildfires that have negative health effects and result loss of pasture land. Climate change is projected to threaten the lichen ecosystems in high latitudes and increases competition with other vegetation, especially vascular plants [67], but on the other hand, the predicted warming will decrease the cold period and days with snow cover increasing utilization of other vegetation for forage [69]. Predicted warming will increase heat stress among humans and reindeer. Changes in precipitation, increased heat stress, insect harassment, and changes in snow conditions in winter have an effect on predation and reindeer population dynamics $[69,70]$. It is predicted that productivity of reindeer forage will probably increase, but the nutritive value and quality could decrease [67].

Weather-related accidents were predicted to either decrease [18] or increase [71]. Based on the interviews, the risk for accidents has increased among reindeer herders. Changes in the carrying capacity of ice, snow quality, and formation are likely to increase the risk for transport-related accidents and in the mountain region risk for avalanches can increase. Based on available knowledge, the primary health effects of climate change are likely to increase among Saami reindeer herders. Saami reindeer-herding models differ regionally and vary from semi-nomadic to local, and effects of climate change and adaptation possibilities thus vary significantly. Based on available evidence, it is not possible to estimate how the climate change influences different reindeer-herding models. Climate change is estimated to have both negative and 


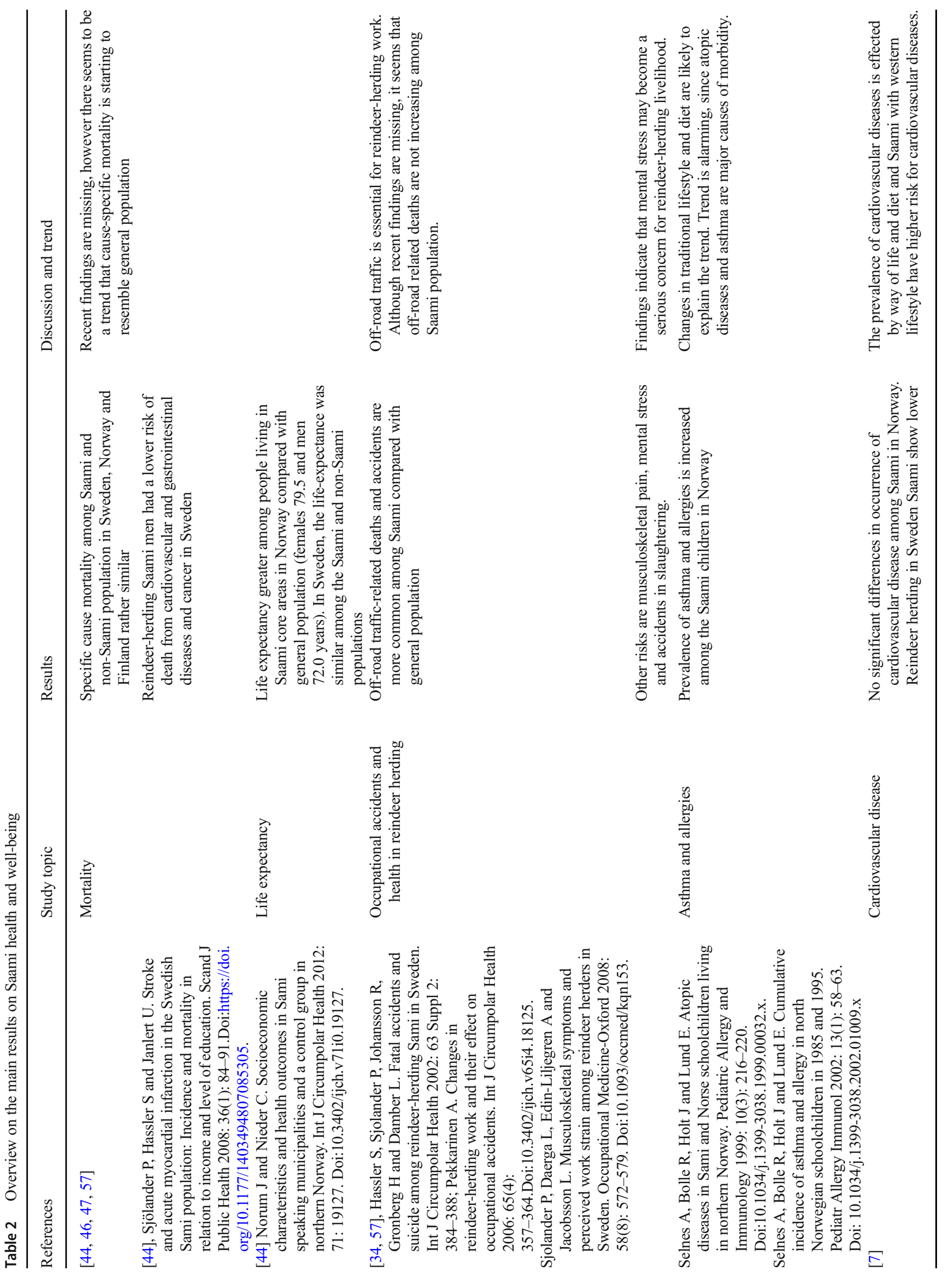




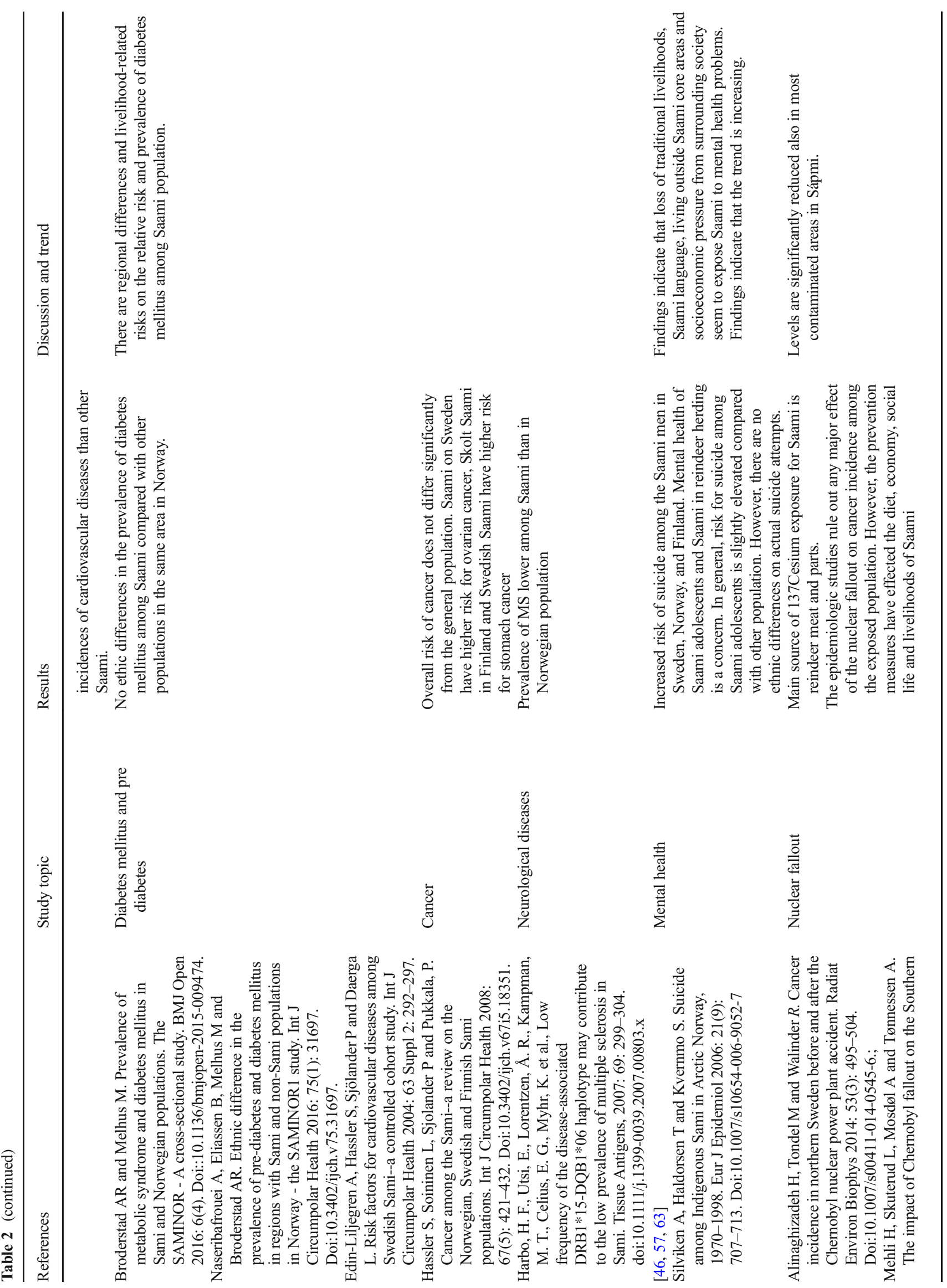




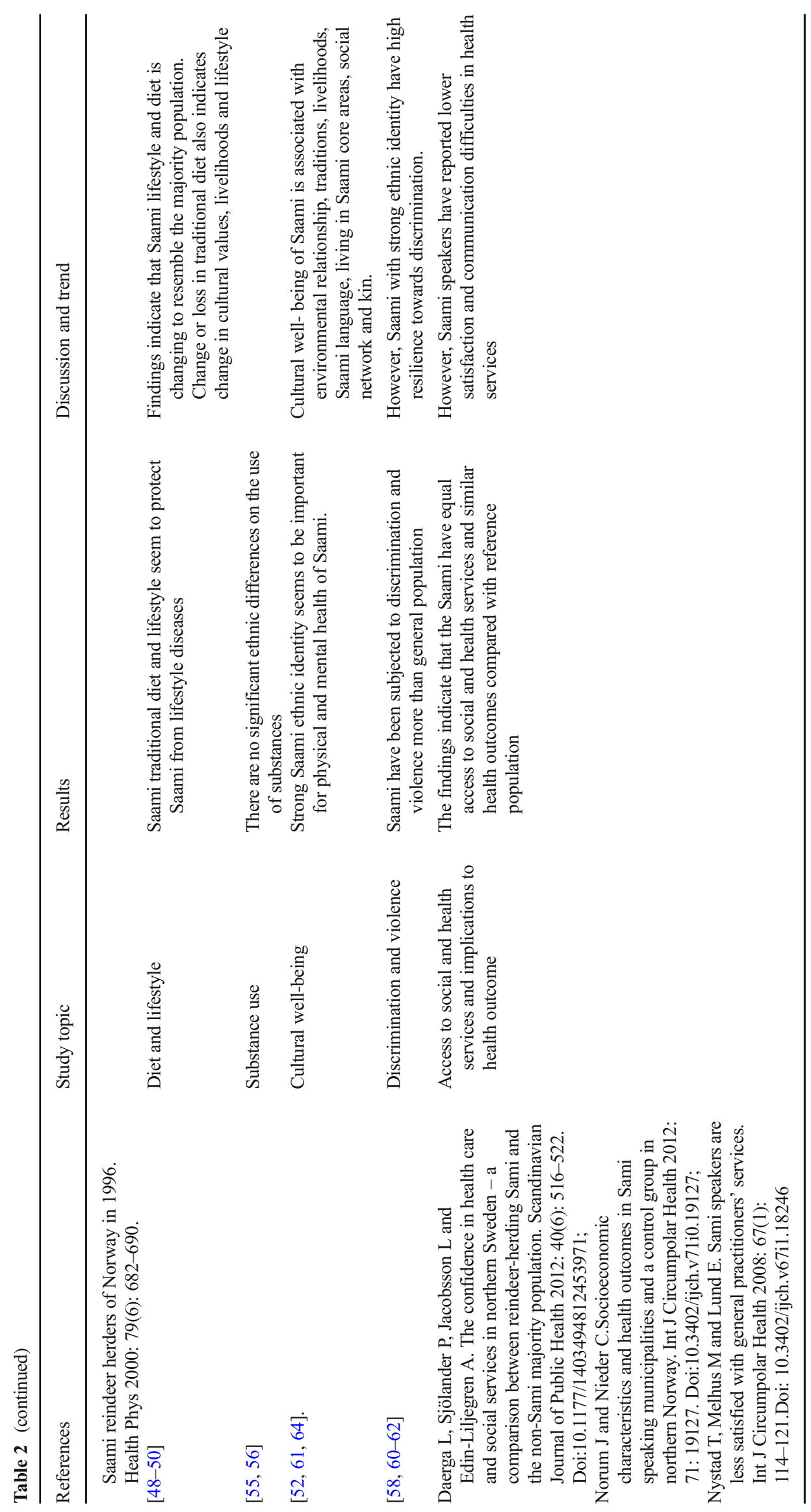


positive effects for reindeer herding. However, the net balance is likely to vary significantly regionally depending on geography, local climate, environment, adaptation and mitigation measures, competing land uses, social system, and Saami population, reindeer-herding models, governance, and socioeconomic factors.

\section{Secondary Effects of Climate Change}

Our search identified only a few studies on the secondary effects of climate change. Northern-Atlantic Oscillation (NAO) produces mild winter weather that creates difficult pasture conditions for reindeer. The NAO incidents are expected to increase in future and climate is likely to become more variable in Sápmi region [69]. The NAO incidents have a negative effect to the winter survival of reindeer. Based on evidence from fieldwork, the increased NAO incidents have contributed to the changes in reindeer-herding practices. Warm winters will promote the development of animal parasite outbreaks among reindeers and parasite species are moving northward [72]. Based on available evidence, the most prominent secondary effects are increased outbreaks of animal-borne diseases, indications are that milder weather and less snow cover promote the spread of new diseases northwards [73-75]. Warm winters also promote the survival of geometrid moths that is one of the main drivers for vegetational change in Sápmi. Increase in precipitation increases erosion and risks for accidents.

Arctic snow cover is a storage for contaminants and heavy metal pollution and reduced snow day cover and increased precipitation can expose humans to these pollutants [18].

\section{Tertiary Effects}

The effects of climate change on the environment and livelihood are likely to influence the future expectations, which may induce mental health problems. Climate change had created fear for future and together with socioeconomic and governance pressure these can be overwhelming. The fear is focused on the future of Saami culture and way of life and disappearance of cultural knowledge and traditions. Herders have reported on increased stress, anxiety, worrying, and depression $[16 \bullet \bullet, 31 \bullet, 35,76,77]$.

Climate change adaptation and opening new resources can limit the adaptation possibilities in Sami reindeer herding by diminishing pastures. Hydropower development has influenced significantly Saami reindeer herding and culture [78] and climate change is likely to change conditions more favorable for hydropower development [18]. Wind power development is already affecting the range selection of reindeer and to the rights of Saami $[27,79]$ and increased temperatures will increase the productivity of boreal forest and expansion of boreal forest to new areas creating land-use competition and opening new possibilities for forestry.

\section{Adaptation and Mitigation}

Climate adaptation and mitigation were approached in the identified studies from two perspectives: (1) adaptation in reindeer herding to the adverse effects of climate change and (2) reindeer as a tool for climate adaptation. We could not identify any studies that discussed how the whole Saami culture and other livelihoods could adapt to the climate change. Findings indicate that adaptation possibilities are limited and available measures are flexible use of pasture land, use of vast environmental knowledge, herding, provide nutrition with supplementary feeding, or fell trees to gain reindeer access to arboreal lichen. Human-animal relationship and reindeer-herding traditions form a basis for adaptation measures $[31 \bullet, 43,80]$. There is evidence that adaptation measures have cultural effects. Reindeer herders fear that the use of supplementary nutrition changes profoundly their cultural livelihood [81], and similar concerns have been raised on the use of GPS-technology on reindeer [82]. Based on fieldwork data, supplementary feeding and GPS use are means for adaptation in difficult conditions, but they have also important cultural effects and may erode the cultural knowledge of the reindeer herder, which can reduce the adaptive capacity of reindeer-herding culture in the future. Reindeer become tamer due to the use of supplementary nutrition and it affects the range selection of the reindeers.

Reindeer grazing can mitigate the effects of climate change, especially in tundra. Reindeer grazing can protect the tundra biome from shrubification and tree line encroachment $[68,83]$. Incentive grazing in summer increases surface albedo, delays snowmelt and decreases the ground from heating in snowmelt season [84••]. Reindeer in fact is a key species for the environment and Saami inhabiting the area.

\section{Discussion}

Figure 5 summarizes our analysis of the main factors affecting health and well-being of Saami and Sápmi in the changing climate based on available data and application of theoretical framework (Fig. 2a).

\section{Environmental and Cultural Change}

A recently published meta-analysis suggests that climate change is having profound disruptive effects at local levels and that local observations can make an important contribution to understanding the pervasiveness of climate change on ecosystems and societies [17•]. Indigenous communities from the Arctic have reported that weather conditions have been less predictable in the past decades $[85,86]$. Our findings 

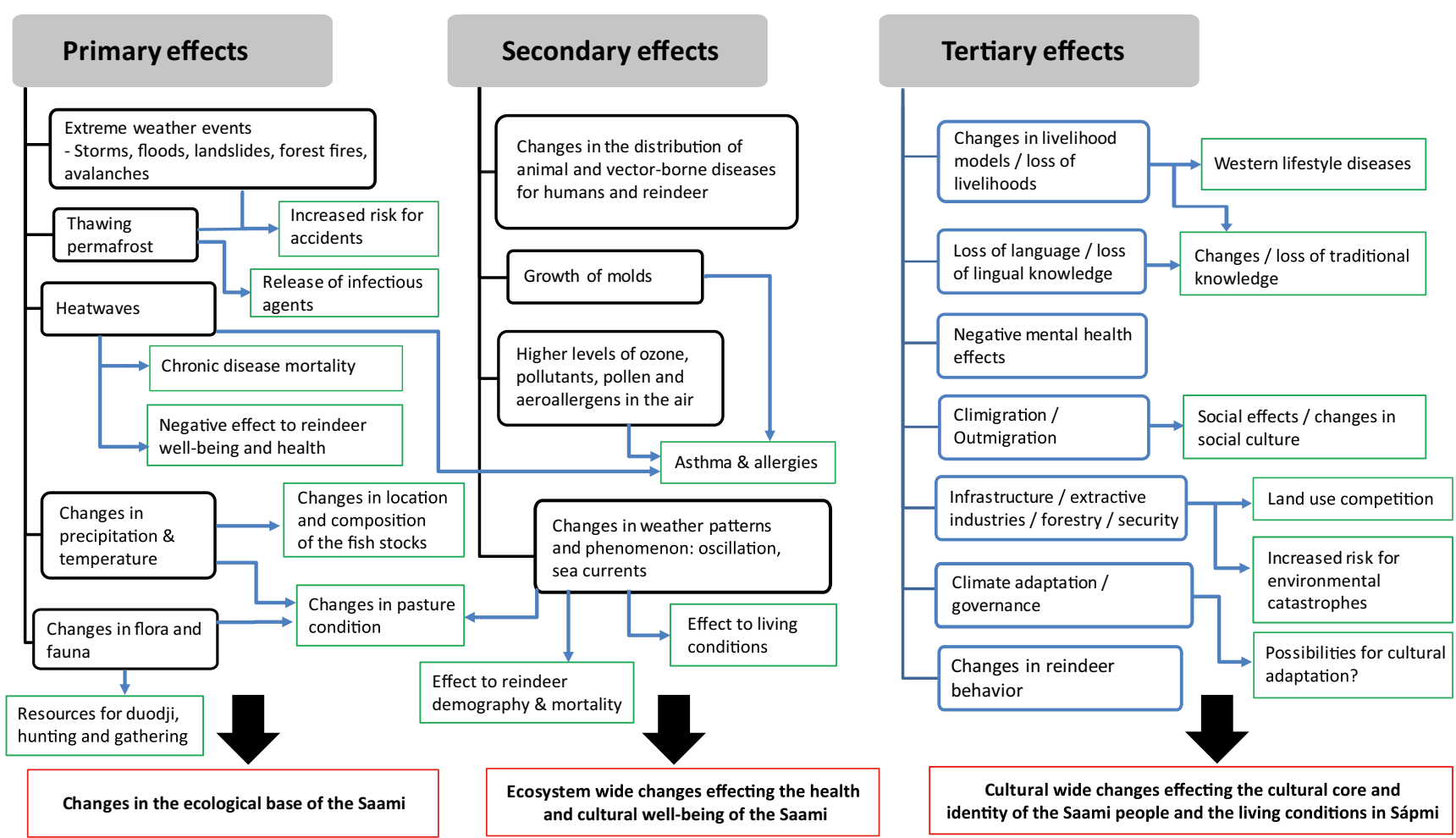

Fig. 5 Main factors affecting health and well-being of Saami and Sápmi in the changing climate based on available data and application of theoretical framework

and fieldwork support these observations. The environmental changes affecting flora and fauna are projected to continue in the Arctic (Table 3) [87].

The melting sea ice and opening of new resources for extraction [88] increase the risk for environmental accidents and are likely to increase land-use competition limiting the possibilities for Saami to adapt to the climate change and possibilities to maintain their traditional livelihoods.

The most important traditional game for the Saami is willow ptarmigan (Lagopus lagopus). A recent study suggests that predation-ptarmigan interactions have changed, most likely due to climate change. Ptarmigans are vulnerable to the temperature fluctuations, increased precipitation, and population declines are likely to occur in changing climate [89]. Fishing is important to both inland and coastal Saami, and especially in coastal area fishing is a viable livelihood [90]. It is projected that changes in temperature effect the movement, location, and demography of fish stock [91]. However, how these changes are likely to influence Saami fishing culture, is not known.

\section{Health Perspectives}

Saami are considered to be highly adapted to Arctic conditions [92] but it is possible that socioeconomic and lifestyle changes have negative effects on adaptive capacity. Our analysis suggests that the lifestyle, diet, and morbidity of the Saami is changing to resemble the majority populations posing threats for both the physical and mental health of the Saami, increasing general morbidity, and making them more vulnerable to the adverse health effects of climate change. Changes in lifestyle and diet expose Saami to cardiovascular disease. Increased climate change-related heat exposure is associated with an increase in cardiac events and especially elderly are vulnerable [93]. We have identified that the livelihood changes may have direct effects on the physical health and cultural well-being of the Saami, which need to studied further and taken into consideration in governance.

Projected changes in temperature are likely to increase the risk of adverse secondary health risks both to Saami and reindeer. Disease outbreaks of pathogens transmitted by ticks and voles could emerge in previous non-endemic geographic areas $[73,94]$. Infectious diseases are likely to have more outbreaks in changing climate and expand to new territories into the north $[74,95]$. Increase in precipitation and flooding events could create conditions favorable for mold growth in homes and this may result in an increase in mold-related disorders and allergies. A new emerging health threat especially in Russian Arctic is the melt of permafrost and release of pathogens [96].

According to AMAP human health report, human exposure to most POPs and metals is declining across many parts of the Arctic but interactions between climate change and contaminant transport have the potential to change human exposure in the Arctic significantly [97]. 


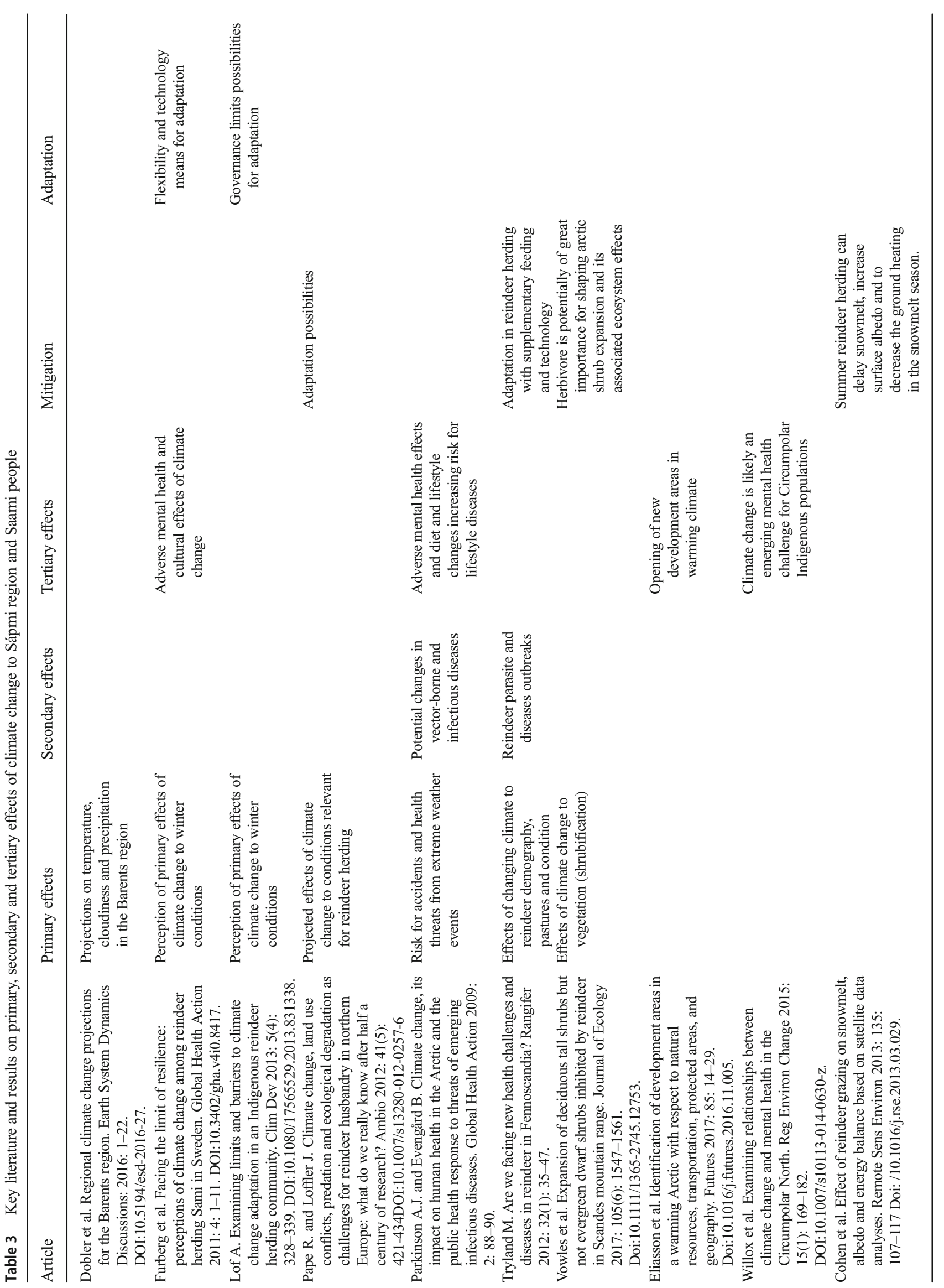


A major contributor to mental health among Arctic indigenous populations is chronic psychosocial stress linked to rapid socioeconomic development and this development is expected to accelerate due to climate change $[98,99]$. Our findings support these observations.

Climate adaptation and mitigation actions such as wind power or hydropower development may increase the stress and mental pressure among the Saami and increase pasture competition. Therefor, climate adaptation and mitigation measures should take into account possible effects to the health and well-being of Saami.

Saami are indigenous people and international covenants obligate the states to protect Saami culture and way of life for future. Health and well-being are basic human rights but in indigenous context culturally meaningful life is a human rights question. Currently there is not sufficient information to appropriately assess health and cultural well-being among the Saami, and therefor, it is challenging to evaluate whether international human rights obligations are met and to what extent adaptation to climate change will be culturally sustainable. Thus, evaluation and long-term monitoring of Saami health and cultural well-being is crucial. Development of a monitoring system is urgent. This study has elaborated the existing knowledge on the relations between environment, culture and health and on the influences of climate change to culture and health of Saami, and shown that the evidence base is limited.

Saami communities around Sápmi face many socioeconomic challenges that threaten their possibilities to maintain their culture and identity. These multi-stress factors weaken the possibilities of Saami to adapt to climate change and maintain their culture. According to the fieldwork data, climate change poses risk for reindeer health and health of reindeer herders in terms of increased risks for accidents and future health prospects. Most prominent health effects are the mental health effects: increased stress, concern over the future of Saami way of live and pressures to abandon traditional Saami lifestyle. Also literature search support these findings.

Our analysis suggests that climate change brings both environmental, economic, cultural and social effects on reindeer herding as economic livelihood and as cultural way of life.

Comparison of the health and well-being of Saami to the health of other indigenous people is possible only at a general level. Comprehensive population-based studies and registrybased data are missing - in Nordic countries ethnic registries are forbidden - and hence, even the definition of a Saami is being disputed. The most comprehensive overview on the health of indigenous and tribal people was published in 2016. The study used general indicators - such as life expectancy and infant mortality - available from registries, excluding morbidity and mental health. The analysis shows that direct comparison of health of indigenous peoples is not possible, because of different status and legal interpretation of indigenousness, differences in data collection methods and indicators and lack of standardization of different methods [100]. However, it can be argued that based on available evidence, the health of Saami is relatively good or better when compared on a general level to other indigenous peoples globally, but overview on cultural well-being and metal health of Saami is missing. More research and development of a monitoring system are needed to understand the health and cultural well-being of Saami in changing climate taking into consideration Saami values and traditions and major drivers for change.

\section{Conclusion}

The multidisciplinary methodology presented here to theorize and understand how climate change effects all aspect of Saami life is central for monitoring the effects and finding ways for culturally sustainable adaptation. Cultural well-being in the Saami context depends on social community and kinship structure, environmental relationship, and traditional livelihoods, and ultimately, possibility to maintain Saami ethnicity and language. Loss of language, culture, and living in urban areas expose Saami to lifestyle changes that can have negative implications for mental and physical health.

Saami have been a study object for centuries in different disciplines, nonetheless holistic analysis is missing on the status and capacities of Saami people to survive and adapt in changing climate. The warming climate and new insight call for a new, comprehensive assessment of the effects of climate change to Sápmi and Saami culture and projected outlook for the future. However, climate change has already influenced Saami culture substantially. Outmigration can in future change to climigration and have a profound effect on the Saami culture and viability of traditional Saami home region. Saami population is small and number of Saami that speak Saami as native language is even smaller. Societal changes and assimilation policies have contributed the loss of language and cultural knowledge and made Saami people even more vulnerable to the negative and cumulative effects of climate change.

A crucial challenge for the future of Saami people and vulnerability among the Saami is the small population size, dispersed settlement, and urbanization that limits the possibilities for cultural adaptation in the changing climate.

\section{Compliance with Ethical Standards}

Conflicts of Interest Jouni Jaakkola and Suvi Juntunen report that this study was partly funded by Finnish Cultural Foundation (Arahat project). The summary of the main findings in this article will be made available for the Saami communities in North Saami language. Klemetti Näkkäläjärvi reports grants and personal fees from Wihuri foundation, during the conduct of the study.

Human and Animal Rights This article does not contain any studies with human or animal subjects performed by any of the authors. 
Open Access This article is distributed under the terms of the Creative Commons Attribution 4.0 International License (http:// creativecommons.org/licenses/by/4.0/), which permits unrestricted use, distribution, and reproduction in any medium, provided you give appropriate credit to the original author(s) and the source, provide a link to the Creative Commons license, and indicate if changes were made.

\section{References}

Papers of particular interest, published recently, have been highlighted as:

- Of importance

•- Of major importance

1. IPCC: Climate change: synthesis report. Contribution of working groups I, II and III to the Fifth Assessment Report of the Intergovernmental Panel on Climate Change [Core Writing Team, R.K. Pachauri and L.A. Meyer (eds.)]. IPCC, Geneva, Switzerland; 2014.

2. Nakashima DJ, McLean KG, Thulstrup HD, Castillo AR \& Rubis JT. Weathering uncertainty: traditional knowledge for climate change assessment and adaptation. Paris, UNESCO, and Darwin, UNU; 2012.

3. Mikkonen S, Laine M, Mäkelä HM, Gregow H, Tuomenvirta H, Lahtinen M, et al. Trends in the average temperature in Finland, 1847-2013. Stochastic Environ Res Risk Assessment. 2015;29(6):1521-9. https://doi.org/10.1007/s00477-014-0992-2.

4. Kivinen S, Rasmus S. Observed cold season changes in a Fennoscandian fell area over the past three decades. Ambio. 2015;44(3):214-25. https://doi.org/10.1007/s13280-014-0541-8.

5. Pettersen T, Brustad M. Which Sámi? Sámi inclusion criteria in population-based studies of Sámi health and living conditions in Norway - an exploratory study exemplified with data from the SAMINOR study. Int J Circumpolar Health. 2013;72. https://doi. org/10.3402/ijch.v72i0.21813.

6. Sámi Parliament of Finland. Number of Saami in the elections for Sámi Parliament 2015. [ Available in Finnish: Saamelaisten lukumäärä vuoden 2015 vaaleissa < http://www2.samediggi.fi/ index.php?option $=$ com_docman\&task $=$ doc_download $\&$ gid $=$ 2831\&Itemid=10 > ] Statistics of Saami Parliament of Finland, Inari; 2015.

7.• Sjölander P. What is known about the health and living conditions of the indigenous people of northern Scandinavia, the Sami? Glob Health Action. 2011;4:8457. https://doi.org/10.3402/gha.v4i0.8457. Provides a review of the studies on health of Saami people in Norway, Sweden and Finland on Saami people including information on mortality, diseases, and risk factors. The life expectancy and mortality patterns of the Saami are similar to those of the majority population in Scandinavia. The traditional Sami lifestyle seems to contain elements that reduce the risk to develop cancer and cardiovascular diseases, but the risk of accidents and suicide is higher.

8. Rasmussen T, Nolan JS. Reclaiming Sámi languages: indigenous language emancipation from East to West. Int J Sociol Lang. 2011;35. https://doi.org/10.1515/ijsl.2011.020.

9. Unesco. Interactive Atlas of the World's Languages in Danger. < http://www.unesco.org/languages-atlas/ > 2017.

10. Näkkäläjärvi K \& Jaakkola JJK. Saamelaiset ja muutos. In: Tennberg M. (ed) Barentsin alue muuttuu - Miten Suomi sopeutuu? Helsinki: Valtioneuvoston selvitys- ja tutkimustoiminnan julkaisusarja 2017; 31/2017: 44-67.

11. CERHhttp://www.oulu.fi/cerh/node/8974). , 2018.
12.• Butler CD, Harley D. Primary, secondary and tertiary effects of eco-climatic change: the medical response. Postgrad Med J. 2010;84(1014):230-23. Introduces theoretical concept of primary, secondary and tertiary effects of climate change to human health and provides an overview on the links between global ecology and human health in changing climate. Brings into attention the challenges of climate-change health effects and urges health professionals to contribute on finding a solution and minimize adverse health effects of climate change.

13. Hardesty DL. The human ecological niche. Am Anthropol. 1972;74(3):458-66.

14. Barth F. Ethnic Groups and boundaries : the social organization of culture difference. Oslo: Universitetsforlaget, 1969; pp. 19.

15. Näkkäläjärvi K. The Siida, Or Sámi Village as the Basis of Community Life. In: Pennanen J \& Näkkäläjärvi K (eds) Siiddastallan. from Lapp communities to modern Sámi life. Inari: Publication of the Inari Sámi Museum ; 5., Sámi museum: 2003; pp. 114-121 .

16.• Furberg M, Evengård B, Nilsson M. Facing the limit of resilience: perceptions of climate change among reindeer herding Sami in Sweden. Glob Health Action. 2011;4:1-11. https://doi.org/10. 3402/gha.v4i0.8417. Brings into attention psychosocial and cultural effects of climate change in reindeer Saami communities in Sweden. The results indicate that Saami have observed climate changing and consequences of the change to their reindeer herding work and culture. The herders also reported increased stress, concern over the future of their livelihood and culture and suggests that the reindeer Saami are facing the limit of resilience in Sweden.

17. Savo V, Lepofsky D, Benner JP, Kohfeld KE, Bailey J, Lertzman $\mathrm{K}$. Observations of climate change among subsistence-oriented communities around the world. Nature Clim Change. 2016;6(5): 462-73. https://doi.org/10.1038/nclimate2958. Presents observations of climate change made by members of substinence-oriented communities from 2,230 localities in 137 countries. Climate change is having profound disruptive effects at local levels around the world.

18. Callaghan TV, Johansson M, Brown RD, Groisman PY, Labba N, Radionov V, et al. Multiple effects of changes in Arctic snow cover. Ambio. 2011;40:32-45. https://doi.org/10.1007/s13280-011-0213-x.

19. Eira IMG, Jaedicke C, Magga OH, Maynard NG, Vikhamar-Schuler D, Mathiesen SD. Traditional Sámi snow terminology and physical snow classification - two ways of knowing. Cold Reg Sci Technol. 2013;85:117-30. https://doi.org/10.1016/j.coldregions.2012.09.004.

20. Aune S, Hofgaard A, Söderström L. Contrasting climate- and land-use-driven tree encroachment patterns of subarctic tundra in northern Norway and the Kola Peninsula. Can J For Res. 2010;41(3):437-49. https://doi.org/10.1139/X10-086.

21. Kivinen S, Moen J, Berg A, Eriksson A. Effects of modern forest management on winter grazing resources for reindeer in Sweden. Ambio. 2010;39(4):269-78. https://doi.org/10.1007/s13280-0100044-1.

22. Kivinen S, Kumpula T. Detecting land cover disturbances in the Lappi reindeer herding district using multi-source remote sensing and GIS data. Int J Appl Earth Obs Geoinf. 2014;27:13-9. https:// doi.org/10.1016/j.jag.2013.05.009.

23. Akujärvi A, Hallikainen V, Hyppönen M, Mattila E, Mikkola K, Rautio P. Effects of reindeer grazing and forestry on ground lichens in Finnish Lapland. Silva Fenn. 2014;48(3):18 article id 1153. https://doi.org/10.14214/sf.1153.

24. Moen J, Danell O. Reindeer in the Swedish mountains: an assessment of grazing impacts. Ambio. 2003;32(6):397-402. https://doi. org/10.1579/0044-7447-32.6.397.

25. Tommervik H, Bjerke JW, Gaare E, Johansen B \& Thannheiser D. Rapid recovery of recently overexploited winter grazing pastures 
for reindeer in northern Norway. Fungal Ecol 2012: 5(1): 3-15. Doi: https://doi.org/10.1016/j.funeco.2011.08.002.

26. Anttonen M, Kumpula J, Colpaert A. Range selection by semidomesticated reindeer (Rangifer tarandus tarandus) in relation to infrastructure and human activity in the boreal forest environment, Northern Finland. Arctic. 2011;64(1):1-14.

27. Skarin A, Åhman B. Do human activity and infrastructure disturb domesticated reindeer? The need for the reindeer's perspective. Polar Biol. 2014;37(7):1041-54. https://doi.org/10.1007/s00300014-1499-5.

28. Tsegaye D, Colman JE, Eftestøl S, Flydal K, Røthe G, Rapp K. Reindeer spatial use before, during and after construction of a wind farm. Appl Anim Behav Sci. 2017;195:103-11. https://doi. org/10.1016/j.applanim.2017.05.023.

29. Naess MW, Bardsen BJ, Pedersen E, Tveraa T. Pastoral herding strategies and governmental management objectives: predation compensation as a risk buffering strategy in the Saami reindeer husbandry. Hum Ecol Interdiscip J. 2011;39(4):489-508. https:// doi.org/10.1007/s10745-011-9398-7.

30. Hobbs NT, Andren H, Persson J, Aronsson M, Chapron G. Native predators reduce harvest of reindeer by Sami pastoralists. Ecol Appl. 2012;22(5):1640-54. https://doi.org/10.1890/11-1309.1.

31. Löf A. Examining limits and barriers to climate change adaptation in an indigenous reindeer herding community. Climate Dev. 2013;5(4):328-39. https://doi.org/10.1080/17565529.2013. 831338. Discusses the barriers to climate change adaptation and suggests that these can be essentially political requiring governmental intervention. Postulates that marginalized are likely to remain highly vulnerable and have restricted adaptation opportunities, unless there are deliberate structural and institutional transformation.

32. Naess MW, Bardsen B, Fauchald P, Tveraa T. Cooperative pastoral production - the importance of kinship. Evol Hum Behav. 2010;31(4):246-58. https://doi.org/10.1016/j.evolhumbehav. 2009.12.004

33. Daerga L, Edin-Lijegren A, Sjolander P. Quality of life in relation to physical, psychosocial and socioeconomic conditions among reindeer-herding Sami. Int J Circumpolar Health. 2008;67(1):826. https://doi.org/10.3402/ijch.v67i1.18223.

34.•• Edin-Liljegren A, Daerga L, Sahlén K, Jacobsson L. Psychosocial perspectives on working conditions among men and women in reindeer breeding in Sweden. J Northern Stud; J Northern Stud. 2017;11(2):31-47. Presents most recent findings on the health of Saami involved in reindeer herding in Sweden. The research material includes questionnaire, workshops and interviews conducted in Reindeer Saami communities. Based on the study material, both men and women are exposed to psychosocial risk factors in their reindeer herding work. The study reported also gender differences on the status and health among reindeer Saami. The study highlighted that reindeer herding for Saami is a way of life, not merely an occupation.

35. Kaiser N, Näckter S, Karlsson M, Salander RE. Experiences of being a young female Sami reindeer herder. J Northern Stud. 2015;9(2):55

36. Rees WG, Stammler FM, Danks FS, Vitebsky P. Vulnerability of European reindeer husbandry to global change. Clim Chang. 2008;87(1):199-217. https://doi.org/10.1007/s10584-007-9345-1.

37. Olsen LS. Sami tourism in destination development: conflict and collaboration. Polar Geogr. 2016;39(3):179-95. https://doi.org/10. 1080/1088937X.2016.1201870.

38. Turunen M, Vuojala-Magga T. Past and present winter feeding of reindeer in Finland: herders' adaptive learning of feeding practices. Arctic. 2014;67(2):173-88. https://doi.org/10.14430/arctic4385.

39. Wheelersburg RP, Gutsol N. Traditional Saami reindeer herding village resource territories on the western Kola Peninsula, Russia.
Polar Rec. 2010;46(238):222-32. https://doi.org/10.1017/ S0032247409990106.

40. Vladimirova V. "It is not our reindeer but our politicians that are wild:" contests over reindeer and categories in the Kola Peninsula, Northwestern Russia. Arct Anthropol. 2014;51(1):24-40.

41. Trosterud T. Language assimilation during the modernisation process: experiences from Norway and North-West Russia. Acta Borealia. 2008;25(2):93-112. https://doi.org/10.1080/ 08003830802496653 .

42. Nyseth T, Pedersen P. Urban Sami identities in Scandinavia: hybridities, ambivalences and cultural innovation. Acta Boreal. 2014;31(2): 131-51. https://doi.org/10.1080/08003831.2014.967976.

43. Riseth JÅ, Tømmervik H, Bjerke JW. 175 years of adaptation: North Scandinavian Sámi reindeer herding between government policies and winter climate variability (1835-2010). J For Econ. 2016;24:186-204. https://doi.org/10.1016/j.jfe.2016.05.002.

44. Hassler S, Johansson R, Sjolander P, Gronberg H, Damber L. Causes of death in the Sami population of Sweden, 1961-2000. Int J Epidemiol. 2005;34(3):623-9. https://doi.org/10.1093/ije/dyi027.

45. Näyhä S. Low mortality from ischaemic heart disease in the Sámi district of Finland. Soc Sci Med. 1997;44(1):123-31. https://doi. org/10.1016/S0277-9536(96)00265-1.

46. Soininen L, Pukkola E. Mortality of the Sami in northern Finland 1979-2005. Int J Circumpolar Health. 2008;67(1):43-55. https:// doi.org/10.3402/ijch.v67i1.18227.

47. Tynes T, Haldorsen T. Mortality in the Sami population of North Norway, 1970-98. Scand J Public Health. 2007;35(3):306-12. https://doi.org/10.1080/14034940701226159.

48. Brox J, Bjørnstad E, Olaussen K. Hemoglobin, iron, nutrition and life-style among adolescents in a coastal and an inland community in northern Norway. Int J Circumpolar Health. 2003;62(2):130 41. https://doi.org/10.3402/ijch.v62i2.17547.

49. Brustad M, Parr CL, Melhus M, Lund E. Childhood diet in relation to Sámi and Norwegian ethnicity in northern and midNorway - the SAMINOR study. Public Health Nutr. 2008;11(2): 168-75. https://doi.org/10.1017/S1368980007000432.

50. Ross AB, Johansson A, Vavruch-Nilsson V, Hassler S, Sjolander P, Edin-Liljegren A, et al. Adherence to a traditional lifestyle affects food and nutrient intake among modern Swedish Sami. Int J Circumpolar Health. 2009;68(4):372-85. https://doi.org/10.3402/ ijch.v68i4.1737.

51. Nilsen H, Utsi E, Bønaa KH. Dietary and nutrient intake of a Sami population living in traditional reindeer herding areas in north Norway: comparisons with a group of Norwegians. Int $\mathbf{J}$ Circumpolar Health. 1999;58(2):120-33.

52. Nystad T, Melhus M, Brustad M, Lund E. Ethnic differences in the prevalence of general and central obesity among the Sami and Norwegian populations: the SAMINOR study. Scand J Public Health. 2010;38(1):17-24. https://doi.org/10.1177/ 1403494809354791.

53. Eliassen B-M, Graff-Iversen S, Melhus M, Løchen M-L, Broderstad AR. Ethnic difference in the prevalence of angina pectoris in Sami and non-Sami populations: the SAMINOR study. Int J Circumpolar Health. 2014;73. https://doi.org/10.3402/ijch. v73.21310.

54. Spein AR. Substance use among young indigenous Sami - a summary of findings from the North Norwegian Youth Study. Int J Circumpolar Health. 2008;67(1):124-36. https://doi.org/10.3402/ ijch.v67i1.18248.

55. Kaiser N, Nordström A, Jacobsson L, Renberg ES. Hazardous drinking and drinking patterns among the reindeer-herding Sami population in Sweden. Subst Use Misuse. 2011;46(10):1318-27. https://doi.org/10.3109/10826084.2011.577884.

56. Omma L, Sandlund M. Alcohol use in young indigenous Sami in Sweden. Nordic J Psychiatry. 2015;69(8):621-8. 
57. Ahlm K, Hassler S, Sjolander P, Eriksson A. Unnatural deaths in reindeer-herding Sami families in Sweden, 1961-2001. Int J Circumpolar Health. 2010;69(2):129-37. https://doi.org/10.3402/ ijch.v69i2.17432. Presents empirical evidence that alcohol plays an important role in unnatural deaths among reindeerherding Saami in Sweden.

58. Eriksen AM, Hansen KL, Javo C, Schei B. Emotional, physical and sexual violence among Sami and non-Sami populations in Norway: the SAMINOR 2 questionnaire study. Scand J Public Health. 2015;43(6):588-96. https://doi.org/10.1177/ 1403494815585936.

59. Hansen KL. Ethnic discrimination and health: the relationship between experienced ethnic discrimination and multiple health domains in Norway's rural Sami population. Int J Circumpolar Health. 2015;74:25125. https://doi.org/10.3402/ijch.v74.25125.

60. Omma LM, Holmgren LE, Jacobsson LH. Being a young Sami in Sweden. J Northern Stud. 2011;5(1):9.

61. Friborg O, Sørlie T, Hansen KL. Resilience to discrimination among indigenous Sami and non-Sami populations in Norway: the SAMINOR2 Study. J Cross-Cult Psychol. 2017;48(7):100927. https://doi.org/10.1177/0022022117719159.

62. Nystad K, Spein AR, Ingstad B. Community resilience factors among indigenous Sami adolescents: a qualitative study in Northern Norway. Transcult Psychiatry. 2014;51(5):651-72. https://doi.org/10.1177/1363461514532511.

63.• Stoor JPA, Kaiser N, Jacobsson L, Salander Renberg E, Silviken A. "We are like lemmings": making sense of the cultural meaning(s) of suicide among the indigenous Sami in Sweden. Int J Circumpolar Health. 2015;74. https://doi.org/10.3402/ijch.v74. 27669. Brings onto focus the current mental health condition among indigenous Saami youth in Sweden. The mental health of Saami youth is connected into to status of Saami and possibilities to maintain Saami traditions and livelihoods. Suicide in considered a way out in a situation where Saami have no longer possibilities to maintain their culture and identity.

64. Tervo H, Nikkonen M. "In the mountains one feels like a dog off the leash" - Sámi perceptions of welfare and its influencing factors. Nordic J Nurs Res. 2010;30(4):9-14. https://doi.org/10. 1177/010740831003000403.

65. Nicolai SS, Saus M. Acknowledging the past while looking to the future: conceptualizing indigenous child trauma. Child Welfare. 2013;92(4):55-74.

66. Turi AL, Bals M, Skre IB, Kvernmo S. Health service use in indigenous Sami and non-indigenous youth in North Norway: a population based survey. BMC Public Health. 2009;9:378. https:// doi.org/10.1186/1471-2458-9-378.

67. Turunen M, Soppela P, Kinnunen H, Sutinen M, Martz F. Does climate change influence the availability and quality of reindeer forage plants? Polar Biol. 2009;32(6):813-32. https://doi.org/10. 1007/s00300-009-0609-2.

68. Vowles T, Gunnarsson B, Molau U, Hickler T, Klemedtsson L, Björk RG, et al. Expansion of deciduous tall shrubs but not evergreen dwarf shrubs inhibited by reindeer in Scandes mountain range. J Ecology. 2017;105(6):1547-61. https://doi.org/10.1111/ 1365-2745.12753.

69. Moen J. Climate change: effects on the ecological basis for reindeer husbandry in Sweden. Ambio. 2008;37(4):304-11. https:// doi.org/10.1579/0044-7447(2008)37[304:CCEOTE]2.0.CO;2.

70. Weladji RB, Holand O. Influences of large-scale climatic variability on reindeer population dynamics: implications for reindeer husbandry in Norway. Clim Res. 2006;32(2):119-27. https://doi. org $/ 10.3354 /$ cr032119.

71. Turunen MT, Rasmus S, Bavay M, Ruosteenoja K, Heiskanen J. Coping with difficult weather and snow conditions: reindeer herders' views on climate change impacts and coping strategies.
Climate Risk Manag. 2016;11:15-36. https://doi.org/10.1016/j. crm.2016.01.002.

72. Laaksonen S, Solismaa M, Kortet R, Kuusela J, Oksanen A. Vectors and transmission dynamics for Setaria tundra (Filarioidea; Onchocercidae), a parasite of reindeer in Finland. Parasit Vectors. 2009;2:3. https://doi.org/10.1186/1756-3305-2-3.

73. Desvars A, Furberg M, Hjertqvist M, Vidman L, Sjöstedt A, Rydén $\mathrm{P}$, et al. Epidemiology and ecology of tularemia in Sweden, 1984-2012. Emerg Infect Dis J. 2015;21(1):32-9. https://doi.org/10.3201/eid2101.140916.

74. Wu X, Lu Y, Zhou S, Chen L, Xu B. Impact of climate change on human infectious diseases: Empirical evidence and human adaptation. Environ Int. 2015;86:14-23.

75. Evengård B. Vulnerable populations: health of humans and animals in a changed landscape. Circumpolar Health Supplements. 2013;72:58. https://doi.org/10.3402/ijch.v72i0.22447.

76. Kaiser N, Ruong T \& Salander Renberg E. Experiences of being a young male Sami reindeer herder: a qualitative study in perspective of mental health. Int J Circumpolar Health 2013: 72(0). Doi: https://doi.org/10.3402/ijch.v72i0.20926

77. Konstantinov Y. Socioeconomic life of climate change: extensivity in reindeer husbandry in relation to synergies between social and climate change (Kola Peninsula). Acta Boreal. 2010;27(1):44-65. https://doi.org/10.1080/08003831.2010. 486925.

78. Össbo Å, Lantto P. Colonial tutelage and industrial colonialism: reindeer husbandry and early 20th-century hydroelectric development in Sweden. Scand J Hist. 2011;36(3):324-48. https://doi.org/ 10.1080/03468755.2011.580077.

79. Lawrence R. Internal colonisation and indigenous resource sovereignty: wind power developments on traditional Saami lands. Environ Plan D. 2014;32(6):1036-53. https://doi.org/10.1068/ d9012.

80. Vuojala-Magga T, Turunen M, Ryyppo T, Tennberg M. Resonance strategies of Sami reindeer herders in Northernmost Finland during climatically extreme years. Arctic. 2011;64(2):227-41.

81. Risvoll C, Hovelsrud GK. Pasture access and adaptive capacity in reindeer herding districts in Nordland, Northern Norway. The Polar J. 2016;6(1):87-111. https://doi.org/10.1080/2154896X. 2016.1173796.

82. Andersson E, Keskitalo ECH. Technology use in Swedish reindeer husbandry through a social lens. Polar Geogr. 2016;40(1):19 34. https://doi.org/10.1080/1088937X.2016.1261195.

83. Biuw M, Jepsen J, Cohen J, Ahonen S, Tejesvi M, Aikio S, et al. Long-term impacts of contrasting management of large ungulates in the Arctic tundra-forest ecotone: ecosystem structure and climate feedback. Ecosystems. 2014;17(5):890-905. https://doi.org/ 10.1007/s10021-014-9767-3.

84.• Cohen J, Pulliainen J, Ménard CB, Johansen B, Oksanen L, Luojus K, et al. Effect of reindeer grazing on snowmelt, albedo and energy balance based on satellite data analyses. Remote Sens Environ. 2013;135:107-17. https://doi.org/10.1016/j.rse.2013.03. 029. Presents the effects of reindeer summer grazing on the vegetation, snowmelt timing, surface albedo and ground heating in the arctic tundra is based on fieldwork testing, satellite data and meteorological data. The article brings into attention the role of reindeer in climate change mitigation in the tundra area.

85. Ford JD, Smit B, Wandel J. Vulnerability to climate change in the Arctic: a case study from Arctic Bay, Canada. Glob Environ Chang. 2006;16(2):145-60. https://doi.org/10.1016/j.gloenvcha. 2005.11.007.

86. Lavrillier A. Climate change among nomadic and settled Tungus of Siberia: continuity and changes in economic and ritual relationships with the natural environment. Polar Rec. 2013;49(3):26071. https://doi.org/10.1017/S0032247413000284. 
87. Pecl GT, Araújo MB, Bell JD, Blanchard J, Bonebrake TC, Chen I, et al. Biodiversity redistribution under climate change: impacts on ecosystems and human well-being. Science. 2017;355(6332): eaai9214. https://doi.org/10.1126/science.aai9214.

88. Eliasson K, Ulfarsson GF, Valsson T, Gardarsson SM. Identification of development areas in a warming Arctic with respect to natural resources, transportation, protected areas, and geography. Futures. 2017;85:14-29. https://doi.org/10.1016/j. futures.2016.11.005.

89. Henden J, Ims RA, Yoccoz NG, Killengreen ST. Declining willow ptarmigan populations: the role of habitat structure and community dynamics. Basic Appl Ecol. 2011;12(5):413-22. https://doi.org/ 10.1016/j.baae.2011.05.006.

90. Broderstad EG, Eythórsson E. Resilient communities? Collapse and recovery of a social-ecological system in Arctic Norway. Ecol Soc. 2014;19(3). https://doi.org/10.5751/ES-06533-190301.

91. Svenning MA, Sandem K, Halvorsen M, et al. Change in relative abundance of Atlantic salmon and Arctic charr in Veidnes River, Northern Norway: a possible effect of climate change? Hydrobiologia. 2006, 783:145. https://doi.org/10.1007/s10750016-2690-1.

92. Vasilyev S, Borutskaya S. Anthropological study of Sami from the Kola Peninsula (Russia). Pap Anthropol. 2017;26(2):168-81. https://doi.org/10.12697/poa.2017.26.2.17.

93. De Blois J, Kjellstrom T, Agewall S, Ezekowitz JA, Armstrong PW, Atar D. The effects of climate change on cardiac health. Cardiology. 2015;131(4):209-17. https://doi.org/10.1159/ 000398787.
94. Porretta D, Mastrantonio V, Amendolia S, Gaiarsa S, Epis S, Genchi C, et al. Effects of global changes on the climatic niche of the tick Ixodes ricinus inferred by species distribution modelling. Parasit Vectors. 2013;6(1):271. https://doi.org/10.1186/17563305-6-271.

95. Parkinson AJ, Evengård B. Climate change, its impact on human health in the Arctic and the public health response to threats of emerging infectious diseases. Glob Health Action. 2009;2:88-90. https://doi.org/10.3402/gha.v2i0.2075.

96. Revich B, Tokarevich N, Parkinson AJ. Climate change and zoonotic infections in the Russian Arctic. Int J Circumpolar Health. 2012;71(1):18792. https://doi.org/10.3402/ijch.v71i0.18792.

97. AMAP. AMAP Assessment 2015: Human Health in the Arctic. Arctic Monitoring and Assessment Programme (AMAP), Oslo, Norway; 2015.

98. Silviken A, Kvernmo S. Mental health and suicide. In: Young TK, Bjerregaard P, editors. Health transitions in Arctic populations. Toronto: Toronto University Press; 2008. p. 359-78.

99. Cunsolo Willox A, Stephenson E, Allen J, Bourque F, Drossos A, Elgarøy S, Kral M, Mauro I, Moses J, Pearce T, MacDonald JPand Wexler L. Examining relationships between climate change and mental health in the Circumpolar North. Reg Environ Chang 2015: 15(1): 169-182. Doi:https://doi.org/10.1007/s10113-014-0630-z.

100. Anderson I, Robson B, Connolly M, Al-Yaman F, Bjertness E, King A, et al. Indigenous and tribal peoples' health (the LancetLowitja Institute Global Collaboration): a population study. Lancet. 2016;388(10040):131-57. https://doi.org/10.1016/ S0140-6736(16)00345-. 